\title{
Jorge de Lima: a clausura do divino
}

Antônio Carlos Secchin

Universidade Federal do Rio de Janeiro

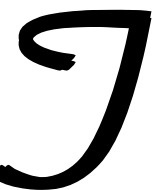

empo e eternidade (1935), A túnica inconsútil (1938) e Anunciação e encontro de Mira-Celi(1950) compõem o tríptico cristão da obra poética de Jorge de Lima. Após a estréia parnasiana com os XIV Alexandrinos (1914) e a adesão ao Modernismo com Poemas (1927), a lírica de Jorge de Lima adquiriria nova inflexão com Tempo e eternidade, livro que também contou, em sua segunda parte, com poemas da autoria de Murilo Mendes.

Não é fortuita a linhagem religiosa na produção de Jorge. Na década de 1920 já cultivava amizade com o filósofo católico Jackson de Figueiredo (1891-1928), tendo, inclusive, colaborado no volume In memoriam, publicado pelo Centro Dom Vital, do Rio de Janeiro, em 1929. Neste livro-homenagem a Jackson, de autoria coletiva, não consta o nome de Murilo Mendes (que só estrearia no ano seguinte, em Juiz de Fora, com Poemas), mas lá se encontram vários poetas identificados com o catolicismo: Augusto Frederico Schmidt, Carlos Magalhães de Azeredo, Durval de Moraes, Murilo Araújo,Tasso da Silveira. Entre todos, destacou-se Schmidt como o grande mentor de nova (ou nem tanto...) direção poética, baseada na revisão, ou mesmo contestação, de algumas das linhas de força do Modernismo de 1922. Os manuais literários falam de 1930 como o início do período modernista "maduro", e para tanto citam os primeiros livros de Murilo Mendes e de Carlos Drummond de Andrade, 
além da Libertinagem, de Manuel Bandeira, mas tendem a omitir a figura exponencial de Schmidt, claramente em conflito com as idéias de 22. Schmidt propunha uma poesia de cunho universalista, de teor filosófico, ritmos largos, longa extensão, dicção grave e visada transcendental, enquanto os modernistas lutavam por uma arte que revelasse raízes brasileiras e se expressasse no ritmo vertiginoso das elipses sintáticas, com maior coloquialidade e humor. À sombra frondosa da poética de Augusto Frederico floresceu o jovem Vinicius de Moraes $(O$ caminho para a distância, 1933), e, de certo modo, desenhou-se o roteiro que iria desembocar na Geração de 45.

Em tal contexto, é singular a posição de Jorge de Lima. Sua produção prévia a Tempo e eternidade se constitui, talvez, na mais consequente adesão de um escritor nordestino ao espírito do Modernismo (que, como sabemos, foi recebido com grandes reservas por autores do porte de um José Lins do Rego e Graciliano Ramos). Por outro lado, o discurso predominante no tríptico cristão aponta para o endosso de uma vertente neossimbolista até então de todo ausente da prática de Jorge de Lima. Viu-se nisso um "retrocesso", como se o proselitismo da fé obscurecesse o vigor da poesia. Até que ponto a crença religiosa poderia converter-se em obstáculo para a grande realização poética? A questão é extremamente complexa, e, certamente, bem poucos críticos veriam nos "livros cristãos" o ápice da poesia de Jorge de Lima. Todavia, a perspectiva oposta tende a ser adotada: estigmatizam-se essas obras aprioristicamente, pelo "pecado" de serem cristãs, como se tal filiação implicasse liminarmente uma desqualificação estética. Em qualquer circunstância, o mais sensato parece ser, simplesmente, trilhar o percurso mais óbvio: aproximar-se das obras sem contemplálas a partir de preconceitos (favoráveis ou restritivos) oriundos da posição ideológica nelas contida. Desse modo, o que soaria, em conjunto, digno de louvor ou reprovação pode revelar 
matizes, apontar veredas, escapar da apreensão monolítica que subjaz no discurso apressadamente condenatório ou encomiástico.

Tempo e eternidade abre-se com a divisa "Restauremos a poesia em Cristo" e é dedicado "A Ismael Nery, na eternidade". Os 44 poemas do livro consignam 80 referências a Deus, Senhor, Cristo, Jesus e Pai, sem contar os pronomes que remetem a tais substantivos, como "Tu", "Vós", "Aquele" etc. Personagens do Antigo Testamento - em especial, Salomão e Davi - também são evocados com relativa frequência pelo poeta que, em "Amo a solidão", declara: "Amo a velha paisagem bíblica". Em linhas gerais, a obras se revestem de uma tonalidade sombria e noturna, de desalento frente aos (des)caminhos humanos, e de crença na sublimação através da arte e da fé. A viagem humana - sem destino ou fundamento é metaforizada, nos textos iniciais, pela figura de um Capitão perdido no mar ("Onde é que fica a minha ilha?"). A resposta virá três poemas adiante: "Ando naufragado,/ando sem destino,/quero Tua mão/para me salvar". Portanto, se é o ímpeto de libertação que move o ser humano, e o faz lançar-se ao oceano, não deixa Jorge de Lima de fomentar um discurso de submissão frente à onipotência do divino: alcançar a liberdade do homem através de sua paradoxal "clausura" no porto seguro da tutela de Deus. No intuito de atingir a purificação redentora, atua o poeta como porta-voz do caos, disseminando imagens apocalípticas, como em "O poeta perdido na tempestade" ("A tempestade, Senhor! A tempestade / mais do que a tempestade a vossa ira") e em "Ao som da sétima trombeta": "Os espíritos imundos subiram/ para o ar semelhante a rãs / martirizando os mercadores / que se fizeram onipotentes/no excesso de suas iniquidades". Se o tempo humano é "sujo", marcado pela injustiça, esmera-se o poeta em abstrair a História, recorrendo a espaços edênicos onde ela ainda não existia, ou a espaços apocalípticos, onde 
ela não mais existirá. Nesse sentido, os míticos "princípio antes do princípio" e "fim após o fim" se enlaçam, pois obedecem à mesma estratégia de suprimir, no homem, o que ele contenha de acidentalmente humano, para valorizar o que nele préexiste ou persiste de essencialmente divino. A ilusória sintonia com seu presente histórico é apenas uma pseudo-anuência de que o poeta se vale para desqualificá-lo, sob a acusação de que a temporalidade gera indesejáveis ou incontroláveis mudanças: "Aceito os dias com seus cinemas, seus bondes,/ seus flertes, suas praias de banho, sua atualidade./Mas deixaime ver no meio dessa conturbação/ o que está acima do tempo, o que é imutável".

O poeta além dos homens, Deus acima do poeta. Eis como se inicia "Distribuição da poesia": "Mel silvestre tirei das plantas,/ sal tirei das águas, luz tirei do céu./ Escutai, meus irmãos: poesia tirei de tudo/ para oferecer ao Senhor". Poesia, simultaneamente, como instância de força - pelo poder criador, que mimetiza o divino - e de fragilidade, ao submeter a própria potência a uma função evangelizadora situada para além de seu domínio. A oscilação entre a grandeza e a pequenez do artista se revela em vários títulos de poemas: "Pelo vôo de Deus quero me guiar", "O poeta perdido na tempestade", "A voz acima das portas", "Poeta, poeta não podes", "Quero ser ensinado por Deus", "Sou para me salvar sobre as tábuas da Lei", "O poeta vence o tempo", "O poeta diante de Deus", "A poesia está muito acima".

Alguns poemas, todavia, fazem descortinar um horizonte menos sombrio, menos toldado de mortes e de expiações. Referimo-nos aos textos emoldurados por aquelas "velhas paisagens bíblicas", onde afloram pulsações de vida e de desejo. Não por acaso, quando o poeta se "despersonaliza" em Davi e Salomão, recalca-se o viés culposo do sexo, que se manifesta, então, de modo quase brutal, em contraste com a 
elocução "elevada" da maioria dos poemas. Observe-se o registro nada transcendental de "Canção de Davi na janela": "A mulher de Urias estava tomando banho./ Eu vi a mulher de Urias./ Peitos mais belos eu nunca vi./.../Não sou mais poeta,/troco meu trono/ pelos dois peitos. / Se olho o mundo vejo os dois peitos./Se olho o céu vejo os dois peitos". Em nível menos ostensivamente erótico, mas do mesmo modo afirmador da disponibilidade para a aventura da vida, se situam os versos de "Convite de Salomão": "Essa manhã não conhece a morte, amada minha, e os pássaros vão subindo/ para o sol, para alargar a claridade".

A túnica inconsútil conserva a atmosfera religiosa do livro anterior, expressa, na maioria dos 72 poemas, na opção pelo discurso mais caudaloso: versos livres com longas sílabas, poemas extensos, ou até mesmo a supressão do verso em prol do "poema em prosa" por duas ocasiões: na última delas("Ode da comunhão dos santos"), que encerra o volume, o texto se espraia por uma dezena de páginas. Também alguns títulos se dilatam para bastante além do padrão habitual, a exemplo de "Confissões, lamentações e esperanças a caminho de Damasco", "Um anjo de tentação baixou junto ao poeta" e "O direito da primogenitura e o direito dos novos patriarcas". O metro longo pode acabar confundindo-se com o padrão do versículo bíblico, e é provável que tal semelhança tenha sido expressamente buscada por Jorge de Lima, inclusive pela utilização abundante da conjunção aditiva " $\mathrm{e}$ " em início de verso (leia-se "O manto do poeta"). A essa espécie de simulação retórica do original bíblico se soma um conteúdo, em geral, bastante ortodoxo em relação aos valores de verdade expressos no livromatriz, fazendo com que, em alguns momentos, tenhamos a sensação de lermos mais uma paráfrase de ensinamentos cristãos do que propriamente textos de uma voz individualizada. Seria fastidioso enumerar todas as ocorrências desse fenômeno, pelo 
qual o poeta se retrai para circunscrever-se ao papel de portavoz ou alto-falante de Deus. Bastam uns poucos exemplos: "A mão do Redentor te aponta o caminho certo" ("O homem - ser processional"); "[O poeta] se senta com Cristo à direita do Pai" ("O poeta no templo); "e o bem e o mal sempre brotando da árvore;/e as sementes, como nas parábolas sagradas"("Olha antes a semente"). Consoante a esse discurso de reiteração de certezas, soa o tom profético de "As trombetas" e de "Contemplação", que afirma a redenção pelo caminho do sofrimento: "Mas o fogo do Inferno há de vir te caldear/ ou ou te extinguir ou te experimentar também./ E serás entregue aos areais desertos / que arderão a teus pés com uma fogueira imensa".

Cabe assinalar a diferença de estratégias e de resultados entre um cristão propagando sua crença por meio de poemas (como parece ser o caso dos trechos acima transcritos) e um poeta criando poemas a partir de fundamentos cristãos, mas sem redundá-los. Na primeira ocorrência, a simbologia é externa ao texto, que dela será mero suporte: a verdade (irmã da poesia) já estaria nas Escrituras, e, com mínimas intervenções, o cristão a repete e propaga. Na segunda, o processo de simbolização é interno, fruto da vivência e da criação do poeta, que, mesmo valendo-se de alusões bíblicas, elaborará um objeto híbrido e enigmático, pela convivência ou tensão da mitologia bíblica com a mitologia do próprio artista. Nesse filão, a meu ver, se encontram os melhores textos de $A$ túnica inconsútil, tramados a partir da reelaboração subjetiva dos elementos bíblicos. Citemos "O grande circo místico" (que mais tarde serviria de base para um espetáculo musical de grande sucesso); "A morte da louca" ("Onde andarás, louca, dentro da tempestade"); "Poema às ingênuas meninas" ("Ó ingênuas meninas de minha terra,/ se quereis ver o enorme edifício em frente ao mar, vinde!/.../Abaixo da superfície 
quieta do oceano/ vêm peixes cegos e famintos foragidos dos grandes / comer os detritos do edifício"); e "Vós precisais dormir", típica demonstração de que o fluxo poético pode dialogar com referenciais imprevistos na lei: "Ó tosses, asmas, máquinas de costura,/ jogadores, sonâmbulos, marés, feiticeiros, palhaços, / vós precisais dormir". Em todos esses textos está presente a questão religiosa (quase sempre, pelo viés salvacionista), o que não os impediu de se realizarem esteticamente, uma vez que não se limitaram a redundar ensinamentos previamente estabelecidos. Destaquemos ainda, ou sobretudo, "O nome da Musa" e "Convite para a ilha", representantes do escasso quinhão propriamente lírico do volume. O primeiro, em vez da paráfrase, recorre à antífrase do texto bíblico ("Não te chamo Eva,/ não te dou nenhum nome de mulher nascida") e projeta a amada numa dimensão cósmica: "Amo contemplar-te nos cardumes das medusas que vão para os mares boreais / ou no bando das gaivotas ou dos pássaros revoando/ sobre as terras geladas". Num livro que, como o anterior, se iniciou com a sombria invocação do oceano - mar de naufrágios, de mortos e destroços - não deixa de ser, quase literalmente, uma ilha-oásis o poema "Convite para a ilha". Locus amoenus, de natureza pródiga e acolhedora, a ilha de Jorge de Lima parece dialogar com outro espaço paradisíaco de larga fama na literatura brasileira: a Pasárgada de Manuel Bandeira, estampada em Libertinagem. Repositório do que pode haver de melhor no mundo, eis o território descrito por Jorge de Lima, a que também não faltam algumas inserções tópicas de outros célebres "paraísos" evocados por nossa poesia ("A canção do exílio", de Gonçalves Dias e "Meus oito anos", de Casimiro de Abreu): "Ao norte dá tudo: baleias azuis,/ o ouriço vermelho, o boto voador./.../Ao sul o que há? - há rios de leite,/ há terras bulindo, mulheres nascendo/.../ Convido os rapazes e as raparigas / pra ver esta ilha, correr nos seus bosques,/ nos vales em flor, nadar nas lagunas,/ / brincar de 
esconder, dormir no areal,/ caçar os amores que existem por lá./.../ E as sestas? Que sestas!A brisa é tão mansa!/ Há redes debaixo dos coqueirais,/ sanfonas tocando, o sol se encobrindo,// as aves cantando canções de ninar".

Comparado aos dois livros anteriores, Anunciação e encontro em Mira-Celi apresenta-se como o mais monolítico; tratase de um conjunto, numerado em sequência, de 59 poemas, dos quais dois em prosa (os de número 1 e 26), oito em metros curtos (15 a 18, 30, 32, 51 e 57) e todos os demais no padrão do verso longo já preponderante em A túnica inconsútil. A publicação tardia (1950) do volume poderia confundir o leitor, na medida em que se consideraria Mira-Celi uma retomada do discurso religioso após um suposto interregno representado pelos Poemas negros, de 1947. O livro, todavia, já estava redigido em 1943, inserindo-se assim, sem quebra cronológica, como a terceira e consecutiva face do tríptico cristão de Jorge de Lima. O que o singulariza frente a Tempo e eternidade e A túnica inconsútil é a intensificação alegórica aliada a um hermetismo prenunciador da atitude poética de Invenção de Orfeu (1952). Perpassa a obra um projeto unitário, narrativo, tramado embora sem relações de causa/efeito. A promessa de narração já se delineia nas linhas iniciais do texto ("O inesperado ser começou a desenrolar as suas faixas em que estava escrita a história da criação passada e futura"). Como que preparando o leitor para o caráter enigmático do que o espera, o poeta adverte: "Pouca gente encontrará a chave deste mistério", e se refere a seu "misterioso poema sempre por terminar". Se, de um lado, abre-se campo para uma mitologia particular na elaboração de imagens, revestindo-se o texto, por isso mesmo, de um teor de maior de arbitrariedade ("À noite, as flores são vísceras / e pulsam como sanguíneos vasos;/ muitas descem da encosta para fecundar os peixes que, pela manhã, são aves"), por outro o livro escapa da tutela de um certo alinhamento 
compulsório ao cristianismo, o que o confinaria à discutível condição de mera paráfrase da palavra bíblica.

Se, eventualmente, o tom dogmático ainda se manifesta ("Todos os séculos e dentro de todos os séculos - todos os poetas,/ desde o início, foram cristãos pela esperança que continham"), é inegável que, em muitos poemas, ocorre uma fusão ou confluência entre mitos pretéritos, bíblicos e uma afirmatividade discursiva que privilegia a incomensurável potência do verbo poético: "Era como se fosse uma irmã mais nova ou um desdobramento de meu ser / talvez a última deusa construída por mim".

O criador (com "c", minúsculo e humano) dispõe de salvo-conduto para investir nas mais ambíguas conexões, pois, como ressalta no poema 38, "não procureis / um nexo naquilo/ que dizem os poetas". Mesmo assim, um nexo - ainda que expresso sob configurações heterogêneas - se estabelece entre vários poemas do livro, formando uma espécie de "núcleo feminino" de Mira-Celi, e constituindo-se num dos pontos altos do volume. O poeta passeia por muitas musas, algumas delas com nomes (Albertina, Lenora) ou enredos colhidos de empréstimo a outros autores. O poema 30, onde são nítidas as ressonâncias de Edgar Allan Poe, pauta-se pela concisão formal em meio a uma coletânea maciçamente transbordante e desmesurada no que se refere a métrica e ritmos. Nesse poema, a contenção dos heptassílabos, de algum modo, prenuncia o desejo de uma "vontade de forma" frente ao fluxo do caos. Pouco depois, avançando na mesma via, a da conjugação do delírio ao rigor, Jorge de Lima nos brindaria com a concisão e o depuramento de seu Livro de sonetos (1949). Mas essa já é uma outra (e menos sagrada) história. 


\section{Resumo}

Análise crítica de Tempo e eternidade, A túnica inconsútil e Anunciação e encontro de Mira-Celi, livros que compõem o tríptico cristão da obra poética de Jorge de Lima.

\section{Résumé}

Analyse critique des livres Tempo e eternidade, A túnica inconsútil et Anunciação e encontro de Mira-Celi, lesquels constituent le triptyque chrétien de l'ouvrage poétique de Jorge de Lima. 